\title{
Conditional Cash Transfer Breaks the Chain of Poverty for Next Generation
}

\author{
Elly Kuntjorowati \\ Ikawati \\ Sri Yuni Murtiwidayanti \\ Trilaksmi Udiati \\ Center for Research and Development of Social Welfare Services \\ Ministry of Social Affair \\ Jalan Kesejahteraan Sosial No 1. Yogyakarta \\ Indonesia 55002
}

\begin{abstract}
This research is an evaluation of a conditional social assistance program called the family hope program (PKH). PKH or CCT is a poverty alleviation program aimed at very poor households with the aim of increasing human resources through improving children's health and education. The research problem posed is how the influence of PKH or CCT in the fields of health, education, and the economy in breaking poverty for the next generation, as well as supporting factors and obstacles to the implementation of the program. The research objective was to determine the influence of PKH or CCT in the fields of health, education, and the economy in breaking poverty for the next generation, as well as supporting factors and obstacles to program implementation. The research method uses the mix method namely quantitative and qualitative. The results of the study showed that PKH or CCT had an effect on the education, health and economy of beneficiary families. Recommendations require the role of local government, especially in updating data to the right target.
\end{abstract}

Keywords: CCT, Poverty, Next Generations.

\section{Introduction}

Poverty can be described as a condition that is lacking in meeting basic human needs which include clothing, food, shelter, the need for healthy living, the need for education and the need to get awards (Elly Kuntjorowati, 2016). According to BPS data, the number of poor people in Indonesia in March 2018 reached 25.95 million people (9.82 percent), a decrease of 633.2 thousand people compared to September 2017 which was 26.58 million people (10.12 percent ).

In Indonesia there are still many poor households that cannot meet the basic needs of education and health because the root causes of problems occur both on the RTSM (demand) and service (supply) side. On the poor households side, the biggest reason for not continuing school is because there is no cost, working to make a living, feeling that education is sufficient. In addition to the health side, the reason for RTSM is because it cannot finance maintenance or health care for family members because of low income levels.

Latin American countries were the first to introduce conditional cash transfers (CCT), and in recent years, a few Asian countries have also been doing so (e.g. Indonesia, India and the Philippines) (Devesh Kapur, Partha Mukhopadhyay, Arvind Subramanian, 2008). In 2007 the Government of Indonesia launched Hope Family Program (PKH), the first conditional cash transfer programme in Indonesia. The programme seeks to improve the quality of human capital by providing cash transfers conditional on households accessing specified health and education services. The PKH or CCT helps to reduce the burden of household/family expenditure for very poor households (the immediate consumption effect), while investing in future generations through improved health and education (the human capital development effect). This combination of short- and long-term assistance is the government's strategy to sustainably lift PKH recipients out of poverty. Requirements that must be met by beneficiaries, especially in terms of health and education of children, it is in the interest of child development to become a healthy and intelligent generation(Kemensos RI, 2017).

$\mathrm{PKH}$ in Indonesia is designed to help the poorer clusters of the population in the form of conditional assistance. This program is expected to be sustainable at least until 2015 and be able to contribute to accelerate the achievement of the Millennium Development Goals (or MDGs). 
There are at least 5 components of the MDGs that are supported through PKH, namely the reduction of extreme and starving poor population, the achievement of basic education, gender equality, reducing infant and under-five mortality, and reducing maternal mortality. In Indonesia there are still many very poor households (RTSM) who cannot fulfill basic education and health needs due to the root of the problems that occur both on the RTSM (demand) and the service side (supply). On the RTSM side, the biggest reason for not continuing school is because there is no cost, working to make a living, feeling that education is sufficient. In addition to the health side, the reason for RTSM is that it is unable to finance maintenance or health care for family members due to low income levels.

The problems that caused the low access of very poor households to education and health include the unavailability of health and education services that are affordable by RTSM. Service costs that are not covered by RTSM and the distance between the place of residence and the location of services that are relatively far away are the main factors.

The low number of family health is very poor and not optimal in the process of child development, especially at $0-5$ years. Ministry of Social Affairs data for the number of neglected children in Indonesia until 2016 departed 4.1 million children. Based on this background, this research was conducted with the title CCT Breaks the Chain of Poverty For Next Generations .

The research question is how is the effectiveness of CCT or PKH in the health sector in breaking the next generation of poverty chains? How effective is CCT or PKH in education in breaking the next generation of poverty chains? What is the effectiveness of CCT or PKH in the economic sector in breaking the next generation of poverty chains? What are the supporting and inhibiting factors in program implementation?

The purpose of the study is to know the effectiveness of CCT or PKH in the health sector in breaking the next generation of poverty chains? Knowing the effectiveness of CCT or PKH in education in breaking the next generation of poverty chains? Knowing the effectiveness of CCT or PKH in the economic sector in breaking the next generation of poverty chains? Knowing the supporting and inhibiting factors in program implementation

\section{Conditional Cash Transfers}

CCT is the Family Hope Program (PKH) which is a social assistance and protection program that is included in the first cluster of poverty reduction strategies in Indonesia. This program is conditional cash assistance related to education and health requirements. PKH Participants are expected to PKH Participants (hereinafter referred to as Households / Very Poor Families (RTSM / KSM) have better access to utilize basic social services, namely: health, education, food and nutrition, including eliminating social inequality, powerlessness and social alienation so far it is inherent in the poor (Kemensos RI, 2013).

Conditional Cash Transfer (CCT), a term used by the World Bank for Poverty Programs in several Latin American countries which are considered successful in increasing school enrollment rates and the health status of poor families and mothers. The general objective of CCT or PKH is to reduce the number and break the chain of poverty, improve the quality of human resources, and change the behavior of beneficiary families (KPM) that are relatively less supportive of improving welfare., the aim of PKH consists of: Improving the socio-economic status of KPM; Improving the health and nutrition status of pregnant women, childbirth mothers, children under five and children aged 5-7 years who have not entered primary school from KPM, Increasing access and quality of education and health services, especially for KPM children. Increasing the level of children's education KPM.

Conditional requirements for receiving PKH benefits include expectant mothers receiving prenatal check-ups, newborns and toddlers receiving post-natal care and health check-ups, and children aged 6 to 18 attending nine-year compulsory education. The benefit is paid quarterly. Between 2007 and 2012, the annual benefit ranged from Rp600,000 to a maximum of Rp2.2 million per year, depending on the family's status (with an average of Rp1.4 million per family per year). In 2013 there was an increase in the benefits, with the average benefit increasing to Rp1.8 million per family per year.

PKH is expected to help beneficiary families (hereinafter referred to as KPM) have better access to utilize basic social services for health, education, food and nutrition including eliminating social inequality, helplessness and social alienation that has been inherent in the poor. The service process starts from the validation of data compiled by the Central Statistics Agency and sent to the Ministry of Social Affairs of the Republic of Indonesia responsible for completing and approving the list of PKH recipients. To carry out this responsibility, the PKH Implementing Unit (UPPKH) conducted a series of assemblies to review data on the very poor households of prospective beneficiaries, and approved a list of final PKH recipients.

Not all poor households fulfill the requirements, the boundary points are set for very poor households that are below the poverty line, and by 2018 the number of beneficiary families is around 10,000,000. Through the following table it can be seen the accuracy of these targets in four locations (Elly Kuntjorowati, 2016). 
There is a lot of literature that records the impact of conditional cash transfer programs such as PKH. This program has made children smart and healthy thanks to PKH (Elly Kuntjorowati, 2016), the program has improved the education achievements of poor families (Schults,T.P., 2004) and has a spillover effect on educational achievements of non-poor families (Bobonis, G and F, Finan, 2005); creating multiplier transfer effects through independent investments (Getler,P and M.Rubio, 2005).

Since it began, there have been a number of studies that have tried to assess its impact. Examination of different places and field surveys has been carried out by various agencies, both domestic and international. In an initial effort, Bappenas (2009) tried to conduct a quantitative assessment using randomized household-based interventions, with measurements before and after intervention in care and control. Improving maternal and child health status (Gertler,P, 2004); reduce nutritional deficiencies (Hoddinott, J. and E. Skoufias, 2004); improvement of the local economy (Coady, D. and R.L. Harris, 2001); and further reduce inequality and poverty (Soares, F.V., S. Soares, M. Medeiros and R.G. Osorio, 2006). The stages of program implementation began with tiered program socialization from the central to regional levels regarding understanding of rights and obligations, coordination with local governments, especially the validation of program target data, distribution of social assistance, stabilization and evaluation. The process of channeling aid through state-owned banks includes Bank Mandiri, Bank BRI. Indicators of program success are measured by improving social welfare, education and health of beneficiary families (Kemensos RI, 2017).

Since the launch of PKH, however, there have been continuous improvements in the system to support program implementation. Management information systems and verification system compliance, for example, now function using the next generation social welfare information system (SIKSNG). At the end of 2015, more than 85 percent of households is a component of the SIKSNG system. Also, changes to implementation procedures deal with a number of problems that are marked by the most recent assessment. For example, recipients of services are now also added to the elderly and disabled. Current payment schedule through state association banks (BNI, Bank Mandiri, BRI) This changes have an impact on the program in promoting positive health and education behavior is expected to be greater.

\section{Poverty}

According to Law No. 13 of 2011 concerning Handling of the Poor, it is stated that the so-called poor people are people who have absolutely no source of livelihood and / or have a source of livelihood but do not have the ability to fulfill basic needs that are appropriate for their lives and / or their families .

Poverty is a problem in development which is characterized by development and backwardness then increases to inequality. The poor are generally weak in their business skills and limited access to economic activities, far behind other communities that have higher potential (Ginanjar Kartasasmita, 2006). Poverty is a situation where a person or household has difficulty in meeting basic needs, while the supporting environment does not provide opportunities to improve welfare sustainably or to get out of vulnerability. Poverty is understood as a condition that is influenced by many causative factors or commonly called multidimensional. Poverty is not only measured by income, but also covers a broader range, namely the vulnerability of people or groups of people, men and women, to being poor; and the limited access of the poor in determining public policies that have an impact on their lives (Ade Cahyat, 2004).

In general, the income of the poor is very low so that in terms of per capita income is also low, especially the average number of poor household members is generally more than the non-poor population so that the average per capita income of the population is relatively lower. This situation will be even worse if the unemployment rate in the region is also high. Poverty is a condition that is often associated with needs, difficulties and shortcomings in various living conditions. Poverty can be interpreted as a person's inability to meet basic consumption needs and increase basic consumption needs and quality of life (Rintuh, C. M, 2003). There are two types of poverty measures, namely absolute poverty and relative poverty. Absolute poverty is the inability of a person to exceed the defined poverty line. Whereas relative poverty is related to the difference in income level of a group compared to other groups. Poverty itself is a problem that involves many aspects because it is related to low income, illiteracy, low health status and inequality between types of maternity and poor environment (World Bank, 2004). According to the World Bank, one of the causes of poverty is due to lack of income and assets to meet basic needs such as food, clothing, housing and acceptable levels of health and education. In addition, poverty is also related to the limitation of occupational food and usually those who are categorized as poor do not have jobs (unemployment), and their education and health levels are generally inadequate. Addressing the problem of poverty cannot be done separately from the problems of unemployment, education, health and other issues that are explicitly closely related to the problem of poverty. In other words, the approach must be carried out across sectors, across actors in an integrated and coordinated and integrated manner. The results of the 1990 World Bank study showed that there was a correlation between poor households and the number of family members, especially the large number of unproductive family members. The number of toddlers and children who are still in school in a household is a burden that is not light. 
The cost of meeting food and clothing needs, health care and education is clearly not small. The greater the number of family members, the greater the cost of living must be spent and the greater the chance to become poor. In fact, the poverty level of a household is generally related to the level of health and education. The low income of very poor families causes the family to be unable to meet health and education needs, even to a minimum. Maternal health care for very poor families is often inadequate, causing poor health conditions for babies born or even the high mortality of babies. Based on the Indonesian demographic and health survey (IDHS) in 2012 the maternal mortality rate in Indonesia is still high at 359 per 100,000 live births. This figure is slightly lower when compared with the 1991 IDHS, which is 390 per 100,000 live births (Ministry of Health, 2014).

\section{Next Generations}

The next generation of Indonesia is the current generation that is given provisions for future generations in making Indonesia a more advanced country. To be able to accompany other developed countries, we need to prepare future generations of Indonesia by improving their health and education early on. Education and health are closely related to Indonesia's future generations because health and education are the keys to delivering reliable human resources and can change attitudes and increase one's knowledge In relation to preparing healthy and intelligent future generations, the Indonesian government launches programs intended for households very poor called the Family Hope Program (PKH), which in other countries is called Conditional Cash Transfer (Elly Kuntjorowati, 2016). The aim of this program is to break the poverty chain and improve Indonesia's human resources in the future.

\section{Research Methods}

This type of research is quantitative and qualitative research and mix methods with analysis using percentages. Combination method is a research approach that combines or connects quantitative and qualitative research methods. Combined research methods will be useful if quantitative methods or qualitative methods individually are not accurate enough to be used to understand research problems, or by using quantitative and qualitative methods in combination will be able to get the best understanding (compared to one method) (Creswell, 2009). The technique of collecting data using questionnaires, namely a series of questions asked to respondents, interviews, document use and focus group discussions.

The research locations were in six locations, namely in Pakanbaru City, Tegal City, Buleleng Regency and Bone Regency. Respondents of this study for each city consisted of 54 KPM people, and supporting informants were assistants and social services. Data collection using interviews, observation and documentation.

\section{Beneficiaries Needs for Food And Non Food}

The total respondents of this study were 216 people from four locations, namely in the City of Pakan Baru, Tegal City, Buleleng Regency and Bone Regency, with the characteristics of all women with very poor categories seen from income of Rp. 600,000 per month, so that it is not sufficient to meet non-food needs such as health and education. The quality of poor human resources is low which means productivity is also low which results in low wages. The low quality of human resources is due to low education, the fate of disadvantaged people, discrimination or because of offspring. Furthermore, poverty arises due to differences in access in capital. The three poverty stems from the theory of the vicious cycle of poverty (vicious circle of poverty). The existence of backwardness, market imperfection, and lack of capital will cause low productivity resulting in low income they receive, and this will have implications for low savings and investment. Low investment results in underdevelopment (Mudrajad Kuncoro, 2003). From the results of interviews with 216 respondents in four locations, namely in Pakan Baru City, Tegal City, Buleleng Regency and Bone Regency, it was found that increasing their welfare requires more non-food assistance such as children's health and education. Through the following table it will be known more clearly.

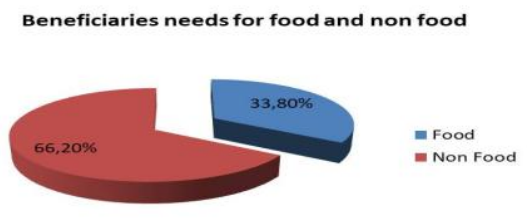

Figure 1 Beneficiaries Needs For Food and Non Food 
From the graph it can be seen that most of the respondents of $66.20 \%$ said that non-food needs such as health and education were far more important than food. For poor households, health is difficult to obtain because the lack of daily nutrition due to poverty makes it difficult to maintain their health. Not to mention expensive medical expenses in clinics or hospitals that are not accessible to the poor. This causes malnutrition or the spread of many diseases.

Education is highly correlated with human resources (HR), but ironically there are still many school-age children who do not go to school. One of the contributing factors is the economic inability of parents to send their children to school (Elly Kuntjorowati, 2016).

\subsection{Effectiveness of CCT for Beneficiaries Social Welfare}

CCT conditional cash transfers are intended to improve family welfare, beneficiaries so that in terms of fulfilling nutrition and health are fulfilled, in terms of fulfilling education for children it is also fulfilled, so that beneficiary family welfare can be improved. Through the following table it will be known more clearly.

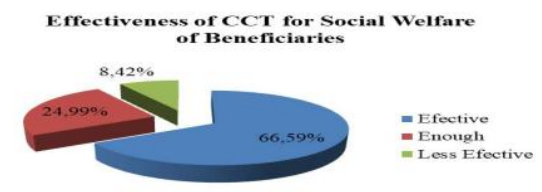

\section{Figure 2 Effectiveness of CCT for Social Welfare of Beneficiaries}

From the graph, it can be seen that most of the respondents of $66.59 \%$ said that the CCT program was effective for improving the welfare of beneficiary families, some of which amounted to $24.99 \%$ said it was effective and a small number of $8.42 \%$ said it was ineffective. From the graph it can be seen also that most respondents said that PKH can improve the welfare of families or very poor households, so that they are more empowered to fulfill family nutrition, health of children from the womb, and education of their children to high school. According to the assistant, every family development session meeting held every month is always informed that PKH assistance is intended to improve the welfare of very poor households by fulfilling children's nutritional, health and education needs, so that children grow and develop in a healthy and smart manner, so that the chain is cut off poverty in future generations.

The evaluation results found that PKH was effective in improving the welfare of beneficiary families. Their monthly expenses averaged 10 percent per family compared to before the program. Households use this extra income for increase their spending on food (especially high protein foods) costs for children's education and health.

\subsection{Accuracy of Goals}

There are several criteria set by PKH or CCT to be able to get the cash assistance directly. One of them is the household whose condition must be very poor. Without meeting these criteria, the people who want to get cash assistance cannot be fulfilled. These criteria are an absolute requirement to be able to get PKH conditional cash assistance. These requirements are socialized to prospective beneficiaries so that they understand the rights and obligations as program beneficiaries. One indicator of the success of the CCT program lies in the accuracy of the target beneficiary families who are women in very poor households, consisting of wives, or adult female children in the household. The name stated on the Social Welfare Card as a sign of PKH participants must be the name of the woman in a very poor household.

The determination is based on data from the social welfare information system next generation (SIKSNG) at the Ministry of Social Affairs. Those who fulfill the requirements will be designated as beneficiary families. Not all poor households fulfill the requirements, the boundary points are set for very poor households that are below the poverty line, and by 2018 the number of beneficiary families is around 10,000,000. Through the following table it can be seen the accuracy of these targets in four locations.

Table 1 Accuracy of Goals

\begin{tabular}{|l|l|l|l|}
\hline Location & Well & Enough & Less \\
\hline Pakan Baru & $90,74 \%$ & $7,42 \%$ & $1,85 \%$ \\
\hline Tegal & $83,33 \%$ & $11,11 \%$ & $5,56 \%$ \\
\hline Buleleng & $72,22 \%$ & $27,78 \%$ & - \\
\hline Bone & $94,45 \%$ & $1,85 \%$ & $3,70 \%$ \\
\hline
\end{tabular}


From the table, it can be seen that in the four research locations, namely in Kota Pakan Baru, 90.74\%, Tegal City 83.33\%, Buleleng Regency $72.22 \%$ and Bone District $94.45 \%$, almost all said well in the sense that the target the right program is that women in very poor households. As beneficiaries, they get a prosperous family card that is used to withdraw the program. The name specified on the card is the name of the woman who is a wife, adult daughter or grandmother. The accuracy of the target also includes the presence of pregnant women, childbirth, toddlers, elementary, middle school, high school, elderly and disability children in these households. A small number of them are quite precise, and only a small number are not right in this household, there are no more women who have given birth, and family recipients.

\subsection{Accuracy of Amount of Assistant Received}

Regarding the accuracy of the assistance received, each beneficiary of the PKH program or CCT is not the same between one recipient and another. This depends on the conditions of each household, as well as the number of children and the level of education that varies between elementary, middle and high school levels. If there are pregnant women the amount of assistance is also adjusted so that it will be very different. For permanent assistance, the amount received is the same, namely five hundred thousand rupiah (Rp. 500,000), then the difference is in the number of school children from elementary school to senior high school, toddlers and pregnant women. The assistance is received every four months and is specifically used for the completeness of education and nutrition needed by the child, and should not be used for school fees, because there is already educational assistance called school operational costs (BOS). The following table will show the accuracy of the amount of assistance received in accordance with the conditions of each household.

Table 2 Accuracy of Amount of Assistant Received

\begin{tabular}{|l|l|l|l|}
\hline Location & Well & Enough & Less \\
\hline $\begin{array}{l}\text { Pakan } \\
\text { Baru }\end{array}$ & $\mathbf{7 0 , 3 7 \%}$ & $\mathbf{3 , 7 0 \%}$ & $\mathbf{2 5 , 9 3 \%}$ \\
\hline Tegal & $\mathbf{9 0 , 7 4 \%}$ & $\mathbf{5 , 3 6 \%}$ & $\mathbf{3 , 7 0 \%}$ \\
\hline Buleleng & $\mathbf{9 2 , 5 9 \%}$ & $\mathbf{1 , 0 5 \%}$ & $\mathbf{5 , 5 6 \%}$ \\
\hline Bone & $\mathbf{7 5 , 9 0 \%}$ & $\mathbf{1 1 , 1 4 \%}$ & $\mathbf{1 2 , 9 6 \%}$ \\
\hline
\end{tabular}

From this table, it can be seen that most respondents both in Pakan Baru, Tegal, Buleleng, Bone, said that the amount of assistance received each month was adjusted according to their household needs of Rp. 650,000. The average amount received per year amounts to Rp. 1,950,000, - up to Rp. 2,150,000, - with the help of permanent details of Rp. 500,000 per year, plus assistance to have children under five, one person Rp. 1,000,000 per year and added assistance has 1 elementary school child of Rp.450,000 , - per year, total assistance received for one year amounts to $\mathrm{Rp}$. $1.950,000$

\subsection{Increasing Human Resources And Breaking the Chain of Poverty}

The general goal of PKH is to reduce the number and break the chain of poverty, improve the quality of human resources, and change the behavior of KPM that are relatively less supportive of welfare improvement. The aim is also to accelerate the achievement of the Millennium Development Goals. : Improve the socio-economic status of KPM; Improving the health and nutrition status of pregnant women, childbirth mothers, children under five and children aged 5-7 years who have not entered primary school from RTSM: Increasing access and quality of education and health services, especially for KPM children. Increasing the level of children's education KPM; Through the following graph it will be known about the accuracy of the increase in human resources to break the poverty chain.

Table 3 Increasing Human Resources And Breaking the Chain of Poverty

\begin{tabular}{|l|l|l|l|}
\hline Location & Well & Enough & Less \\
\hline Pakan Baru & $59,26 \%$ & $37,04 \%$ & $3,70 \%$ \\
\hline Tegal & $79,6 \%$ & $20,4 \%$ & - \\
\hline Buleleng & $59,3 \%$ & $40,7 \%$ & - \\
\hline Bone & $63 \%$ & $37 \%$ & - \\
\hline
\end{tabular}

From the table it can be seen that all respondents in Pakan Baru, Tegal, Buleleng and Bone, all of them said that increasing human resources from an early age through improving education would greatly affect the termination of the poverty chain for future generations. The basic element of human capability is education which plays a central role in overcoming the problem of poverty. Economic problems are a major factor that causes low education participation and high rates of drop out in poor groups. They do not have sufficient funds for schools, because education does require relatively large costs (Sen, Amarta Kumar, 2000). 


\subsection{Administrative Accuracy}

The administrative accuracy in PKH distribution is very important because the beneficiary family data is based on name and address. The beneficiary family data is an integrated database in 2017 from the 2017 Central Bureau of Statistics census which is then submitted to the Data and Information Center at the Ministry of Social Affairs to be managed further through the social net generation (SIKSNG) information system. Beneficiary families must be recorded in the SIKSNG, otherwise they cannot get program assistance. Through the following table, we can find out more.

Table 4 Administrative Accuracy

\begin{tabular}{|l|l|l|l|}
\hline Location & Well & Enough & Less \\
\hline $\begin{array}{l}\text { Pakan } \\
\text { Baru }\end{array}$ & $\mathbf{9 8 , 1 5 \%}$ & - & $\mathbf{1 , 8 5 \%}$ \\
\hline Tegal & $\mathbf{8 7 , 0 4 \%}$ & $\mathbf{3 , 7 0 \%}$ & $\mathbf{9 , 2 6 \%}$ \\
\hline Buleleng & $\mathbf{9 8 , 1 5 \%}$ & $\mathbf{1 , 8 5 \%}$ & - \\
\hline Bone & $\mathbf{7 7 , 8 0 \%}$ & $\mathbf{2 2 , 2 0 \%}$ & \\
\hline
\end{tabular}

From the table it can be seen that most of the respondents in Pakan Baru, Tegal, Buleleng and Bone all said that their data was based on the name and address in the Ministry of Social Affairs. They said that data verification and validation is often carried out by the regional government as updating data. This is done because there may be a family of beneficiaries who have died or moved addresses. The latest data by the program companion will be inputted online through the SIKSNG. Administration incomplete data will be rejected.

\subsection{Impact of PKH or CCT on Health in Four Locations}

After becoming a member of $\mathrm{PKH}$, it is expected that poor household conditions will become better and more empowered so that the family's welfare will increase. Immunization of children under five for families of beneficiaries of PKH is an obligation that must be done, it is to foster a healthy and intelligent future generation. If violated or do not do immunization, PKH assistance can be postponed. Some health requirements that must be done include: pregnant women must have their health checked at the community health center, childbirth must be assisted by medical personnel, children under five must be monitored for growth in integrated service posts, and toddlers must be fully immunized. This shows that PKH is very supportive of the development of healthy and intelligent children and cut off the next generation of poverty chains. Through the following table it will be known more clearly.

\section{Table 5 Impact of PKH or CCT on Health in Four Locations}

\begin{tabular}{|l|l|l|l|}
\hline Location & Well & Enough & Less \\
\hline $\begin{array}{l}\text { Pakan } \\
\text { Baru }\end{array}$ & $\mathbf{5 0 \%}$ & $\mathbf{4 0 , 7 4 \%}$ & $\mathbf{9 , 2 6 \%}$ \\
\hline Tegal & $\mathbf{8 5 , 1 9 \%}$ & $\mathbf{1 1 , 1 1 \%}$ & $\mathbf{3 , 7 \%}$ \\
\hline Buleleng & $\mathbf{5 0 \%}$ & $\mathbf{4 4 , 4 5 \%}$ & $\mathbf{5 , 5 5 \%}$ \\
\hline Bone & $\mathbf{5 0 \%}$ & $\mathbf{4 0 , 8 \%}$ & $\mathbf{9 , 2 \%}$ \\
\hline
\end{tabular}

From the table, it can be seen that most of the respondents in Pakan Baru, Tegal, Buleleng and Bone, said that PKH or CCT was very influential in improving health because from the time of pregnancy the health check-up at the community health center must be helped by medical staff, and children should be immunized complete, of course very influential, because the program facilitator monitors and makes reports about health.

\subsection{Impact of PKH or CCT on Education}

After becoming a PKH participant, children's education is very important, because children who skip truant or do not attend school, PKH assistance can be delayed. The program requires the presence of children in school at least $85 \%$ of school days. Through the following table it will be known more clearly.

Table 6 Impact of PKH or CCT on Education

\begin{tabular}{|l|l|l|l|}
\hline Location & Well & Enough & Less \\
\hline $\begin{array}{l}\text { Pakan } \\
\text { Baru }\end{array}$ & $\mathbf{1 4 , 8 2 \%}$ & $\mathbf{7 4 , 0 4 \%}$ & $\mathbf{1 1 , 1 1 \%}$ \\
\hline Tegal & $\mathbf{8 8 , 8 9 \%}$ & $\mathbf{1 1 , 1 1 \%}$ & - \\
\hline Buleleng & $\mathbf{1 1 , 2 \%}$ & $\mathbf{7 4 \%}$ & $\mathbf{1 4 , 8 \%}$ \\
\hline Bone & $\mathbf{5 5 , 5 6 \%}$ & $\mathbf{3 5 , 1 8 \%}$ & $\mathbf{9 , 2 6 \%}$ \\
\hline
\end{tabular}


From the table it can be seen that most of the respondents in Pakan Baru, Tegal, Buleleng and Bone all said that PKH was very influential on children's education which was useful to improve the quality of human resources so that it would also affect better employment and would break the poverty chain future generations. According to program companion information, they monitored the presence of children in school and checked directly into school, of course this was very influential for children's education.

\subsection{The Impact of PKH For Economic Improvement}

PKH or CCT in addition to improving health and education for beneficiary children, is also expected to be able to improve the family economy. At each monthly meeting held by the facilitator with the beneficiary families, they are informed to form a joint business group to improve the economy. The group is a business group to improve the family economy with Warung business. Through the following table it will be known more clearly.

\section{Table 6 The Impact of PKH For Economic Improvement}

\begin{tabular}{|l|l|l|l|}
\hline Location & Well & Enough & Less \\
\hline $\begin{array}{l}\text { Pakan } \\
\text { Baru }\end{array}$ & $\mathbf{1 2 , 9 6 \%}$ & $\mathbf{2 0 , 3 7 \%}$ & $\mathbf{6 6 , 6 7 \%}$ \\
\hline Tegal & $\mathbf{8 3 , 3 3 \%}$ & $\mathbf{1 6 , 6 7 \%}$ & - \\
\hline Buleleng & $\mathbf{6 6 , 7 \%}$ & $\mathbf{2 0 , 3 \%}$ & $\mathbf{1 3 \%}$ \\
\hline Bone & $\mathbf{6 2 , 9 6 \%}$ & $\mathbf{3 5 , 1 8 \%}$ & $\mathbf{1 , 8 6 \%}$ \\
\hline
\end{tabular}

From the table it can be seen that most respondents said that PKH had an impact on improving the economy, because in each group the beneficiaries were guided by a companion to manage the nine basic food stalls formed by the Ministry of Social Affairs. This joint business group is useful for improving the economy of beneficiary families. The group is in the form of basic food stalls which are jointly managed by beneficiary families.

\section{Supporting and Inhibiting Factors}

Supporting factors include strong support from the central government as the executor and person in charge of PKH or CCT. Clear rules and regulations so that beneficiary families understand their rights and obligations. The identity of the beneficiary families is clear so that they can be processed as PKH members. PKH companion dedication and loyalty in assisting and monitoring beneficiary families in terms of health care and children's education.

Obstacle factor

The lack of local government support related to invalid beneficiary data. Very poor people who do not have a selfidentity so they cannot get PKH social assistance.

\section{Conclusion}

PKH in Indonesia aims to break the chain of poverty for future generations by increasing human resources in the fields of health, education and the economy. From the results of research in four locations, namely in Pakan Baru City, Tegal City, Buleleng Regency and Bone Regency, it is known that PKH is very influential for improving the health of beneficiary families, since the baby is still in the womb until the child is under five years old. In the field of education it is also very influential in improving human resources, because children are required to go to high school. In the economic field they are grouped as a joint business group (KUBE) to manage food stalls established by the Ministry of Social Affairs, to improve the social welfare of PKH beneficiary families, and break the poverty chain.

\section{Recommendations}

It is necessary to update the data on very poor households, so that those who are actually eligible to receive program assistance are not overlooked. Local governments need to help very poor households to get identity cards as a requirement to get PKH assistance. Training is needed to enter data through SIKSNG.

\section{References}

Ade Cahyat. (2004). Bagaimana Kemiskinan Diukur. . . Bulletin Center for International Forestry Research. No 2 Nop 2004., Vol 2.Bobonis,G and F, Finan. (2005). Endogenous Social Interaction Effects in School Participation in Rural Mexico. California: Berkeley,CA, University of California.

Coady, D. and R.L. Harris. (2001). Evaluating Transfer Programs Within a General Equilibrium Framework',. FCND Discussion Paper, No. 110. Washington, DC, International Food Policy Research Institute., No 110.

Devesh Kapur, Partha Mukhopadhyay, Arvind Subramanian. (2008). More on Direct Cash Transfers, 43, Number 47. 
Elly Kuntjorowati. (2016). Anak Tumbuh Cerdas Dan Sehat Berkat Program Keluarga Harapan (Pertama). Yogyakarta: Total Media.

Gertler,P. (2004). Do conditional cash transfers improve child health? Evidence from PROGRESA's control randomized experiment',. American Economic Review.

Getler,P and M.Rubio. (2005). Investing Cash Transfers to Raise Long Term Living Standards. California: Berkeley,CA, University of California.

Ginanjar Kartasasmita. (2006). Pembangunan untuk Rakyat: Memadukan Pertumbuhan dan Pemerataan. Jakarta: Pustaka Cakra.

Hoddinott, J. and E. Skoufias. (2004). 'The Impact of PROGRESA on Food Consumption.' Economic Development and Cultural Change, 53 (1): 37-61., 53 (1), 37-61.

Kemensos RI. (2013). Pedoman Umum PKH 2013. Jakarta: Ditjen Linjamsos.

Kemensos RI. (2017). Pedoman Umum PKH 2017. Ditjen Linjamsos.

Mudrajad Kuncoro. (2003). Ekonomi Pembangunan: Teori, Masalah dan Kebijakan. (Ke tiga). Yogyakarta: UPPAMPYKPN.

Rintuh, C. M. (2003). Kelembagaan dan Ekonomi Rakyat. Jakarta: Dikti.

Schults,T.P. (2004). School Subsidies fo the Poor: Evaluating the Mexican Progress Poverty Program. Journal of Development Economics, 74, 199-250.

Sen, Amarta Kumar. (2000). Development as Freedom. New York: Anchor Books.

Soares, F.V., S. Soares, M. Medeiros and R.G. Osorio. (2006). Cash Transfer Program in Brazil: Impact on Equality and Poverty',. Presented at the International Poverty Centre Working Paper, Brazil.

World Bank. (2004). Mewujudkan Pelayanan Umum bagi Masyarakat Miskin. Jakarta: The World Bank.

\section{Author Profile}

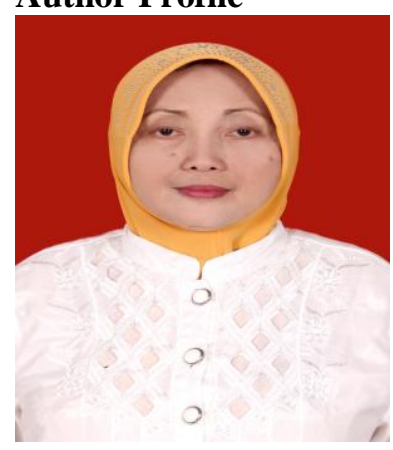

Elly Kuntjorowati received her Dra degree in history from the University of Indonesia in 1984 and her M.SI degree in community empowerment from the Village Community Development School in 2010. Since 1984 to now work at the Ministry of Social Affairs of the Republic of Indonesia, and become a researcher in Center for Research and Development of Social Welfare Services from 1990 until now.

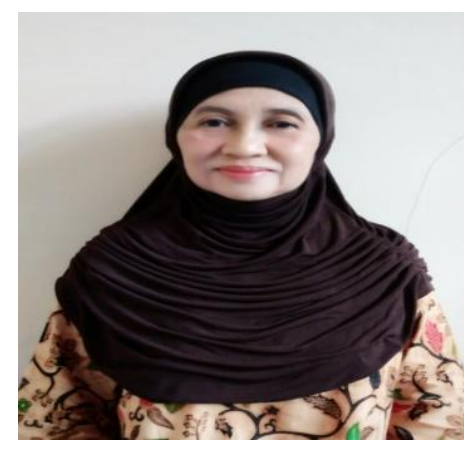

Ikawati received her Dra degree from the Gajah Mada University in 1987. Since 1992 to now work at the Ministry of Social Affairs of the Republic of Indonesia, and become a researcher in Center for Research and Development of Social Welfare Services from 1996 until now. 
Sri Yuni Murtiwidayanti received her Dra degree from the Wiyata Scholars University in 1988. Since 1992 to now work at the Ministry of Social Affairs of the Republic of Indonesia, and become a researcher in Center for Research and Development of Social Welfare Services from 2000 until now.

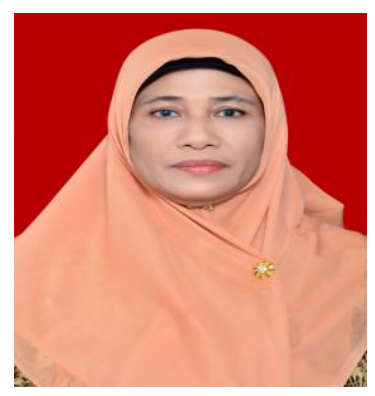

Trilaksmi Udiati received her Dra degree from the Social Wefare High School (STKS) Bandung in 1986 and. Since 1989 to now work at the Ministry of Social Affairs of the Republic of Indonesia, and become a researcher in Center for Research and Development of Social Welfare Services from 1999 until now. 